\title{
Revisiting Creative Teaching Approach in Saudi EFL Classes: Theoretical and Pedagogical Perspective
}

\author{
Sayed M. Ismail ${ }^{1} \&$ Mohamed Ali Mohamed Kassem ${ }^{2,3}$ \\ ${ }^{1}$ Department of English Language, Applied College, Prince Sattam bin Abdul-Aziz University, Saudi Arabia \\ 2 Department of English, College of Science \& Humanities in Al-Kharj, Prince Sattam bin Abdul-Aziz University, \\ Saudi Arabia \\ ${ }^{3}$ Department of Curriculum \& Teaching Methodology, Faculty of Education, New Valley University, Egypt \\ Correspondence: Sayed M. Ismail, Department of English Language, Applied College, Prince Sattam bin Abdul-Aziz \\ University, Saudi Arabia.
}

Received: December 15, 2021

Accepted: January 17, 2022 Online Published: January 25, 2022

doi:10.5430/wjel.v12n1p142

URL: https://doi.org/10.5430/wjel.v12n1p142

\begin{abstract}
The present study aims to address the aspects of similarities and differences between the traditional and the creative teaching approaches in the Saudi EFL context by providing a comparative critical review of literature about the current teaching approaches. The study adopts a comparative critical approach that employs critical comparison to assess, critique, and synthesize the literature on a research topic in a way that enables new theoretical frameworks and perspectives to emerge. It also critically compares the previous studies dealing with creativity in teaching English as a Foreign Language with those dealing with traditional teaching approaches to explore the impediments of the application of the creative teaching approach to teaching English in a Saudi environment. The study has found that the previous studies on creativity and teaching English as a foreign language are in short of a clear understanding of how creativity can be used as an effective teaching approach and they also lack empirical evidence. In addition, there seems to be a conflation of creativity and the traditional teaching approach in the sense that although several studies claimed that they provided a creative teaching approach, their results and findings contradicted their objectives and hypotheses. In most cases, their methods were tailored to offer an impractical and illusory teaching approach, which has nothing to do with creativity. The proposed teaching approaches are incoherent and inhomogeneous which never suits either of them. Therefore empirical studies on creativity and its impact on EFL learners' minds in Saudi Arabia should be initiated.
\end{abstract}

Keywords: creativity, EFL learners, Saudi EFL context, traditional approach

\section{Introduction}

Although many Saudi studies dealing with EFL research have done considerable efforts to integrate creativity with teaching approaches, there are practically no study reports on attempts to integrate creativity with the teaching of a foreign language (see, for example, Rauf, 2015; Samuelson et al.; 2017). The studies tackling the application of creativity to teaching English as a foreign language in Saudi Arabia were restricted to assessing the instructors' and learners' attitudes toward creativity. These studies are not only a few but also iterative (See, for example, Aldujayn, \& Alsubhi, 2020; Albawardi \& Jones, 2019; Al-Jarf, 2015). In addition, there is a remarkable gap between the empirical and critical studies addressing the issue of creativity and its relationship to teaching English in Saudi Arabia. That is to say, there is a crystal-clear gap in the studies dealing — both in quality and quantity - with creative approaches, and their applications to teaching English as a foreign language. Therefore, it has become a pressing issue to revisit creativity and its applications to the Saudi teaching and learning environment to re-evaluate its impact on the mindset of the instructors and EFL learners.

Indeed, while thinking about creativity and how it could be integrated with the teaching approaches of the English language as a foreign language, there are a myriad of questions came to the researchers' minds. However, the researchers will focus only on the following inquiries: Is creativity an individual talent like inspiration and revelation independent of the laws of professionalism and specialization, the application process of which does not follow definite norms and specific rules? How do Saudi instructors and curriculum designers think of creativity and 
innovation? How can they integrate them with the teaching of a foreign language? Are there previous experiences in which creativity was applied to the Saudi teaching environment? Therefore, firstly, the study aims to survey the research addressing the aspects of similarities and differences between the traditional and the creative approaches and their applications to the Saudi Arabia learning environment. Secondly, it aims to examine the studies assessing the attitudes of EFL teachers and learners toward the concept of creativity and its applications to teaching. Thirdly, it traces the studies addressing the obstacles that may prevent teachers from applying creativity to their classrooms. In a nutshell, it is a kind of a critical reflection on how the previous studies perceive, evaluate, critique, and apply the creative teaching approach to teaching EFL in the Saudi context.

The current study is divided into the following sections. The first section is the introduction that outlines the purpose of the study, its significance, objectives, questions, and hypothesis. The second section surveys the gaps uncovered by numerous studies about the adopted teaching approaches of the English language in Saudi Arabia. In other words, it addresses the gap between the theoretical framework of the adopted teaching approaches and their practices in the learning context. The third section is mainly concerned with the methodology of the study that draws on insightful analysis and evaluation of the previous studies, their shortcomings, their gaps, and their contradictory issues in theory and practice. The fourth section is mainly concerned with discussion and analysis and the final is the conclusion. The present study takes into account several issues of concern, which can be subsumed under the following items:

1-The major objective in teaching and learning English in elementary and high schools in Saudi Arabia is the students' marks in the final exams rather than their proficiency in language skills.

2- Speaking and listening skills are not assessed in high and elementary schools.

3- The exams are not designed to measure students' practical and critical thinking skills in the English language; however, they are designed to assess students' capability of retrieving knowledge that often contradicts the innovative and creative teaching approach the major objective of which is to elicit students' critical thinking skills.

\subsection{The Significance of the Study}

The significance of the study has much to do with the pedagogical expectations of the Saudi ministry of education and its educational language planning that focuses on transforming students' theoretical knowledge into practical skills. A creative teaching approach can help learners use their critical thinking skills and enable them to practice the English language with proficiency in real-life situations. It also lies in the fact that English occupies a special position within the Saudi community. It is sometimes considered the sole channel of communication in a wide range of social, administrative, educational, and professional domains. It is used for communication between the Saudis and the vast cohort of foreign laborers who largely participated in the Saudi economy. In essence, high English competence has become an indispensable component of most professional and administrative establishments. Therefore, reviewing the Saudi teaching approaches of the English language with a particular emphasis on creativity and creative teaching approaches is a significant issue.

\section{Review of Literature}

In Saudi Arabia, there is a tremendous interest in research addressing the issues about the approaches of teaching English as a Foreign Language (EFL). Moskovsky (2018) presented a chronological review of EFL-related research conducted by Saudi scholars between 1990 and 2016. The earlier research done in EFL was characterized by its narrow scope where the studies suffered from a lack of variety in the examined topics and did not present creative and innovative solutions for issues relating to the teaching approaches of English. However, after the introduction of the Saudi Government's Scholarship program in early 2000, there have been remarkable improvements-both in quality and quantity - in the studies dealing with EFL research. Moskovsky remarked that the studies conducted in the area of EFL research in Saudi Arabia "fall naturally into several well-established and widely recognized topic areas in the second language (L2) acquisition research|" (p. 6). These topics range from pedagogy, curriculum, teaching approach, teachers' teaching styles, and techniques, teachers' competence, EFL teacher's pre-service and inservice training, the use of new digital technologies, the examination of language attitudes, and motivations, the use of learning strategies by Saudi learners, learning styles, language anxiety, the major language skills, learners' interlanguage (IL) grammar, the impact of learners' native language on the L2 acquisition, the possible effects on the learners' IL system, language planning and language policy, bilingualism to acculturation. In addition, the previous studies on the EFL teaching and learning approach focused largely on the problems facing the teachers and the learners of English.

Other studies have addressed the issue of vocabulary attrition facing EFL teachers in Saudi Arabia (Alharthi, 2014; 
Alharthi, 2012). There is a scarcity in the number of studies dealing with the application of creativity to teaching English as a foreign language. These few studies draw on a narrow scope in the sense that they were descriptive rather than prescriptive. As an illustration, their results have shown that Saudi teachers do not have the autonomy to properly implement the critical thinking pedagogy in their teaching. Teachers in Saudi Arabia are strictly restrained by the traditional approach of teaching, and they follow a curriculum that disabled them to apply innovative and creative teaching approaches (for example, Albedaiwi, 2014; Alnofaie, 2013; Alnefaie \& Gritter, 2016). Unfortunately, these studies neither present realistic interpretations and reliable findings of creativity applications to the Saudi EFL learning environment nor go through the core issues relating to creativity, critical thinking, and their applications. To illustrate, Aldujayn \& Alsubhi (2020) stated that although the EFL teachers in Saudi Arabia did not adopt creative approaches in teaching inside classrooms, the previous studies did not address the reasons why EFL teachers did not use creative approaches while teaching. Aldujayn \& Alsubhi also attempted to perceive Saudi EFL teachers' attitude toward creativity inside classrooms. They found that the participants demonstrated positive attitudes toward creativity itself; however, they were short of the necessary data about the concept of creativity and its application. The findings of the studies on creativity seem to be contradictory as there is a sharp contradiction between the Saudi teachers' belief in creativity and their inability to integrate it with their teaching approach. Such a condition of sheer contradiction appears clearly in Saudi harsh interpretation of religious texts concerning creativity and their relegating creativity to secondary and minor issues like textbook design.

\section{Methodology}

The methodology adopted in the study is a comparative research method based on a critical literature review approach that aims to assess, critique, and synthesize the literature on a research topic The applied method is used to compare the aspects of differences and similarities between traditional and creative teaching approaches in Saudi EFL context. (Baumeister, 1997; Snyder, 2019; Torraco, 2005). Critical reflection upon the approaches is used to evaluate the current status of teaching approaches of English in Saudi Arabia. Critical examination of much research done by many Saudi authors interested in approaches of EFL is also considered teaching where the traditional and creative teaching approaches are compared. This comparison is held in relation to a number of factors. The first factor is contextualization as the contextual elements affecting both creative and traditional teaching approaches are to be critically assessed to learn about the contextual - social, historical, cultural, religious - elements that impede the use of creative teaching approach. The second factor is pedagogical, as it compares the validity and the reliability of the application of the creative method and the traditional method and how far the research conducted in such area could manage to handle properly the integration of creative approach with the traditional teaching approach. The third factor is critical reflection, as a critical and reflective comparison between traditional and creative teaching research done in Saudi context is held to reflect on the Saudis' educationist perception of the creative teaching process, the shortcomings in their application, and how to avoid falling into these shortcomings in future research in a way that helps them apply creativity to teaching approach properly. That is to say, the present research is built on a comparative critical examination of the existing knowledge relating to creativity in teaching English in the Saudi context.

\section{Discussion and Results}

The traditional teaching approach may refer to common practices the results of which are presumably predictable and acceptable. It relies heavily on teacher-centered, teacher-directed instruction where students are required to sit in their seats passively and listen to the lecture attentively (Slavin, 1995; Wang, 2007). In other words, it is characterized by a lecture-based model that follows the teacher-directed system where teachers assume a major responsibility in delivering knowledge to the students who are often passive listeners. Salter (2003) remarked that in the traditional teaching approach "the student is sometimes viewed as an empty vessel waiting to be filled with little or no account given to the prior experiences of the student" (p. 138). The information flows from teacher to student in a one-straightforward direction. This information-transformation model addresses students' lower-order thinking skills, such as memorization, and overlooks the higher levels of thinking skills. The traditional teaching approach also depends upon the teacher's targeted learning outcomes, focusing on learners' acquisition of knowledge through the content-oriented philosophy. The validity and the reliability of the traditional face-to-face approach were questioned by several researchers (Harasim et al1995; Waldron \& McLeskey 2010; Reeves CK \& Kazelskis, 1985; Pietsch \& Williams, 2005). "It is often argued that the traditional approach may not provide students with valuable skills and indeed some even go as far as saying the traditional approach leads to a student not retaining knowledge after exams- they have little or no recall of the body of knowledge learned beyond the end of a semester" (Tularam \& Machisella, 2018, p.129). 
In conservative and traditional societies like Saudi Arabia, teachers often use the traditional teaching approach that has a negative impact on EFL learners' proficiency and language skills. One of the crystal-clear disadvantages of using the traditional approaches is that it not only impedes learners' creative thinking skills but also makes them unable to transform their theoretical knowledge into practical skills. The lack of creative and critical thinking has made EFL learners encounter several difficulties while practicing the English language in their real-life situations (Al-Zahrani, 2017; Fatani, 2016; Elyas \& Michelle, 2008). In other words, plenty of learners are unable to meet the requirements of the labor market and the demands of the recent developments in the economy of Saudi Arabia, and the emerging cultural changes These recent changes require the EFL instructors to foster creative and critical thinking skills in the minds of EFL learners. In addition, the lecturing style has many disadvantages like learners' distraction, learners' disengagement in the classroom, and the lack of using modern technology. Pechenizka \& Zavalna (2020) remarked that the traditional teaching approaches are incommensurate with the mentality of the current generations of students who are deeply immersed in digital space. The virtual world shapes their consciousness and their perception of the outside reality. In addition, the traditional teaching approach of EFL does not provide teachers with the teaching strategies necessary for motivating learners. Therefore, the sessions of the professional development plans should be administered to teachers to improve their teaching and raise their awareness of the disadvantages of the traditional approach.

\subsection{Creativity Definitions from a Theoretical and Pedagogical Perspective}

Creativity is a highly controversial concept, which is transformative. It changes over time and varies according to cultural and socio-economic realities. Carter $(2004$, p.25) remarked that creativity is derived from the Latin creare, meaning 'to make' or 'to produce.' The basic word form is used in Latin mainly in the sense of an original 'divine' creation of the world...it was a divine act of inspiration that resulted in the creation of living creatures." It lies in presenting something novel and original. Thus, it is closely related to originality, novelty, inspiration, genius, individuality, and so on (William, 1983, p. 230; Preminger \& Brogan, 1993, p.455-6,). one of its important definitions is that is "a puzzle, a paradox, some say a mystery. Inventors, scientists, and artists rarely know how their ideas arise. They mention intuition, but cannot say how it works" (Boden, 1994, p. 28). also, Another important definition is the making of novel, innovative and appropriate work (Cropley, 2006). When addressing the relationship between creativity and second language learning from a communicative perspective, creativity is defined as "the process of producing new ideas, contributes to the emergence of rich, complex second-language patterns in learners" (Tin, 2015, p. 437).

This view holds that language is a medium for communicating the ideas and the thoughts of speakers to others. In this way, learners are in dire need to obtain information that enables them to express themselves. The learning tasks aim to help learners produce specific linguistic patterns to express their ideas and thoughts. Therefore, The practice of the English language $d$ is interrelated to creativity simply because "everyday exchanges between people are replete with wordplay, puns, and formal jokes", (Carter, 2004, p.19). Fostering the creative skills of thinking may enable students to deal proficiently with such critical situations while expressing themselves in English. Language acquisition has been transformed into a machine learning system.. the traditional view of creativity was built around misconceived ideas. In other words, creativity does not rest upon communicating specific patterns; however, it helps learners to understand these patterns and adapt them to different contexts they encounter in their lives (Roth \& Duit, 2003, p.870).

The complex/dynamic system theory regarded creativity as the creative process of thinking that produces novel and new ideas, which are closely intertwined with the complex/dynamic processes of our brains (see, for example, Cariani, 1997; De Bot, Lowie, \& Verspoor, 2007; Kim, 2006; Larsen-Freeman \& Cameron, 2008). It is stimulated by several cognitive processes. These stimulated cognitive processes may include two thinking types: chaotic and ordered, as proposed by Finke (1996), or three types of thinking: combinational, exploratory, and transformational, as proposed by Boden (2001). Foreign language acquisition is considered to be a process of creative thinking since the acquisition of a second language entails transforming new ideas, repressed thoughts, linguistic structures, vocabulary, and information into coherent, cohesive, comprehensible, and communicative language patterns. Sokol et.al., (2008) argued that the thinking approach should be integrated with the teaching approaches of English language to produce creative EFL learners. . The integration process is the responsibility of the teacher "who scaffolds learners in the process of building models in response to certain tasks(problems)" (p. 37). Language use has become an increasingly complex process due to the complexity of the contemporary world that contributes largely to the evolution of human language. "Creativity is basic to a wide variety of different language uses, from everyday advertising language to slogans to the most elaborated of literary texts" (Carter, 2006, p.18). Therefore, creativity has become a necessity for both educators and learners of languages, through which they can sort out these complexities 
and become able to use these linguistic skills proficiently (Tomasello, 2000; Slobin, 2005).

Creativity studies in language acquisition have focused on the teaching approaches that allow learners to play tasks; these studies, however, do not answer questions regarding why and how play tasks can help learners improve their critical thinking skills (Carter, 2004; Hrešć, 2016; Johnson, 2017; Sadykova \& Shelestova, 2016) Tin (2016) argued for the importance of creativity for EFL teachers, as creativity contributes to "designing 'communicative' tasks and creating a 'communicative' desire have been the focus of much second-language education, often with an emphasis on using language to talk about known meaning" (p. 433). Creativity motivates learners to develop and learn a complex language (Ellis, 2008; Steels, 2005). In the same vein, Tin remarked that "play task types, such as rulebased games, lead to more complex language patterns as compared to other non-play, transactional episodes or roleplay activities" (p. 435). However, Tin could not determine explicitly how the process of creative thinking affects the learning process as he just posed some questions with open answers such as, what are some conditions that can promote creative processes that, in turn, can contribute to the development and transformation of learner language? Why do some language learning tasks lead to the emergence of complex language patterns and new ideas, whereas others do not? In general, The studies conducted on creativity are divided into four approaches ranging from product, person, process, and environment (Rhodes, 1987). However, a great deal of the studies tackling creativity in teaching and learning languages has focused on the finished product without describing the processes of teaching and learning. That is to say, these studies focused creativity on the learners and ignored deliberately or undeliberately the ways by which the learning process can be creatively motivated. To illustrate, creativity is no longer interested in learners nor teaching and learning processes but it is mainly concerned with a textbook design, and the learning objectives (Al-Qahtani, 2016; Hofweber \& Graham, 2017; Richards, 2013; Schoff, 2016). Fulfilling the conditions of a creative thinking environment for learners and providing the methods necessary for improving the cognitive process in creative thinking has not been adequately studied (Tosey, 2006, p.30).

\subsection{The Barriers toward the Integration of Creativity to Traditional Teaching Approach}

The barriers of creativity in Saudi Arabia range from cultural, social, historical, traditional, cognitive, theological, to environmental. However, the researchers argue that the significant problem with the application of creativity to Saudi context is twofold: the first side of the problem is conceptual, as creativity is misconceived by many Saudis; the second side is geographical, as Saudi Arabia is a large desert area that occupies four-fifths of the Arab Peninsula. It was historically isolated from the external world. Its inhabitants used to lead a nomadic style of life-based on a purely tribal system that cultivates into their minds xenophobic feeling excluding strangers and obstructing different habits, cultures, and traditions. Therefore, creativity is inherently rejected because it deconstructs the purity of the tribal system and undermines xenophobia. A large section of Saudi society believes that creativity paves the way for assimilating and accepting strange values, which are incoherent and inconsistent with the dominating Saudi value system. Nomadism is based on isolation and self-centrism, and tribal purity. Therefore, ideas like difference, hybridity, humanism, and creativity are discredited because these ideas, particularly creativity pose serious threats to the Bedouin's ardent belief in racial and cultural purity.. In addition, creativity is also regarded as a transcendental trait, which negatively affects the introduction of systematic studies that draws on an explicit framework. Besides, the harsh interpretation of Islamic religious text has made a large section of Saudis refrain from the concept of creativity, regarding it as a satanic concept, revealed by the devil to the human mind that may undermine the soul of the Islamic faith. That is to say, in Saudi Arabia, creativity as an idea was traditionally opposed by a large section of both tribal and religious communities. In addition, the orthodox and conservative misinterpretation of Prophet Muhammad's (Peace be upon Him) concept of bid'ah, which is misinterpreted as an equivalent of creativity and innovation, affects negatively people's reception of creativity. Bid'ah is generally believed to be interpreted as a deviation from the true path of the Prophet's teachings, which has nothing to do with creativity. Several studies have remarked the socio-cultural barriers in Saudi Arabia have made teachers resort to using traditional teaching approach for English language learning despite their awareness that using traditional approach has made the "the English language instruction ...embraced less enthusiastically and Saudi children have put off English language learning in the Kingdom of Saudi Arabia" (Ahmad, 2015, p.191).

\subsection{Creativity and Saudi Cultural Background}

Lubart (1999) argued that some Eastern cultures tend to classify creativity as a kind of illusion and hearsay, discrediting it from innovation and originality. These cultures hold a belief that creativity may break with the established conventions of their communities. They reinvented the existing and traditional ideas. This process of the reinvention of tradition is regarded as an act of imitation and misrepresentation rather than an act of innovation and creativity. "In Eastern conceptions of creativity, notions of progression are weaker and the dominant movement is 
circular and restorative" (Carter,2005, p.30). In the same vein, several studies have claimed that Islamic religious teachings have obstructed creativity in the Muslim world and made millions of Muslims across the globe reject the concept of creativity (see, for example, Coleman, 1998; Yerxa, 2016; Bruce, 2013). To verify the truthfulness of this claim, we have to understand the sound meaning of creativity in the Arabic language and its concept in the religious text - the glorious Quran and Sunhat. The Arabic word "khalaq" means "to "create" and God's creation is always distinguished for its creativity. Therefore, in the Arabic language, the word, khalaq is always collocated with abd'a"-khalaqa wa abd'a-" and this collocation refers to creativity." In Lisan Al-Arab dictionary, the Arabic word, $a b d^{\prime} a$ is always used to describe the transcendental beauty of Godly creative acts. When one sees a marvelous beauty and perfection in a tangible or an intangible entity, he will unconsciously say Glorifying Allah, the creator whose creativity baffles the eyes.). Quran abounds with examples calling for creativity, contemplation, and critical thinking. Allah is described in Quran as the wonderful creator "(God is) the Wonderful creator without depending upon any matter or pattern of the heavens and the earth; and when He issues a decree He does but says to it, 'Be' and it comes to be" (Holy Qur'an, 2001, 117). The verse states that God's creation of heavens and earth is inspired by the utmost degree of creativity, beauty, and uniqueness. Creativity is an inherent value in Islamic traditional thinking.

Quran has many verses calling for thinking and meditating, as the word yatfkrun "thinking about" or "speculating about" was mentioned 19 times in the Quran, which is remarkable evidence of the importance of critical thinking in the Islamic culture. Islamic theology derives its principles, judgments, and rulings from inductive and deductive reasoning. The jurisprudential judgments and fatwas in Islamic fiqh are completely derived from deductive and critical reasoning (Iqbal, 2017). Kuppinger (2017) argued that pious Muslims in Europe have significant creative contributions, as European Muslims have become creative urban contributors, cultural producers, and stakeholders. A great of the Saudi English teachers reject unconsciously the application of creativity to their teaching approach and instead they adopt a purely traditional approach. In addition, a conservative section in the Saudi community holds a belief that learning English may undermine the Islamic and traditional values of Saudi society (Al Dameg, 2011; Al-Seghayer, 2013). That is to say, the cultural and historical circumstances have already impeded the adoption of creativity in the Saudi teaching and learning context. Saudi Arabia is almost a conservative society that tends toward the rough application of Islamic religious teachings, which sometimes contradicts the core message of Islamic religion calling for thinking, meditating, and speculating.

\subsection{A Brief Assessment of Saudi EFL Research Done about Creativity}

To understand the barriers toward the application of creativity to EFL teaching in Saudi Arabia, the present study has tried to re-assess the previous studies addressing creativity and teaching English as a foreign language in a Saudi context in connection to the following approaches on creativity: The first approach is known as the psychological approach that uses criteria like the un/measurable nature of creativity, the cognitive processes involved in creative thinking, the relationship between life experience, cultural, historical, and socio-political realities of the learners, the personal traits of creative learners, the motivations necessary for fostering creative thinking into the minds of EFL learners, the acquisition of creativity and so on (Damian \& Simonton, 2015). The second approach is the pragmatic and practical approach, which links creative thinking to problem-solving activities (Elkjær \& Simpson, 2006). The third approach is the psychometric approach that examines creativity in terms of experimentation and empirical studies and quantitative measures (Plucker \& Renzulli, 1999). The fourth is the psychodynamic approach that focuses on examining creativity in highly talented figures, which is focused on the case-study approach (Atkinson \& Wells, 2000). Finally, the biographical approach examines the narrative accounts of the famous historical figures whose creative ideas have changed history and is based on tracing the authentic documents exposing their lives

Al-Qahtani (2016) used the psychometric approach that examines creativity in terms of experimentation and empirical studies and quantitative measures (Plucker \& Renzulli, 1999) He surveyed 45 male ELF teachers and six teachers to examine whether they have practiced creativity in their classrooms. Under the results of the survey, AlQahtani found that the Saudi EFL teachers in high schools did not use creative and innovative teaching approaches inside classrooms and they favor the traditional teaching approach over the creative teaching approach. The lack of creative and critical thinking in Saudi classrooms is considered to be a rather complicated issue where teachers did not rely heavily on fostering critical and creative thinking in the minds of their students. Subsequently, students lack the skill of creativity and critical thinking. A major problem hindering the application of creativity is teachers' negative attitude toward the idea of creativity. Al-Qahtani attributed the negative attitude toward creativity to some factors like the traditional design of textbooks, EFL supervisors, and teachers' lack of awareness of creativity. What is believed to be the causes of the inability to integrate creativity with traditional teaching approaches like the traditional design of textbooks and so on are considered to be the result of the lack of creativity. The author has reached his results based on a hasty generalization, as the sample of the study is not representative at any rate and it Published by Sciedu Press 
cannot measure accurately as well as precisely whether or not Saudi EFL teachers can use creativity. In addition, the studies measuring the attitudes and the perceptions are not often objective and their results may be tailored to fit well with the perspective of the researcher, turning them into biased and prejudiced results.

Aldujayn et al. (2019) also attempted to use the psychometric approach that examines creativity in terms of experimentation and empirical studies and quantitative measures (Plucker \& Renzulli, 1999). However, her study was short of accurately applying the approach of creativity. The study failed to analyze how Saudi EFL teachers could perceive creativity and integrate it with their traditional teaching approach. The study focused on understanding EFL teachers' attitudes toward creativity by adopting a validated survey instrument that is designed to measure the perception of 85 Saudi female teachers about creativity. The study found that the female teachers had a positive attitude toward creativity. Such perceptual studies based on a specific survey lack both accuracy and objectivity. That is to say, questions of the survey may be designed to elicit certain responses from the participants that can agree well with the hypothesis of the researcher. In addition, the sample of the study is too small to measure accurately whether or not Saudi female teachers had a positive response toward creativity. According to the results of the study, although teachers were reported to think of themselves using a creative teaching approach, they did not adopt it in teaching and they were also unable to define creativity. The study did not explain the reasons why the teachers were unable to do so. Al-jarf (2015) attempted to prove that online writing could foster creativity in writing skills for Saudi EFL freshman students. Al-jarf has chosen 38 students who were enrolled in writing, grammar, vocabulary, and reading courses. These students were also enrolled in an asynchronous online course that was used as a supplement to in-class instruction. However, the results of the study did not explain how online courses could foster creativity in the minds of the learners. Zaid (2011) has broken with the mainstream attitude entailing that Islamic culture may impede creativity for both EFL learners and teachers of EFL in Saudi Arabia, as he remarked that those kids who memorized the Qur'an by heart are more creative learners of English than their peers who do not memorize Qur'an. Zaid (2011) argued that Qur'an can be a strong source for teaching thinking skills and creativity. "The relationship between language and religion can be especially evident, for instance, in the context of proselytization and conversion, through which language may help make the supernatural believable or, at least, conceivable" (Harding 1987; Stephen 1997).

Al-Qahatani \& Lin (2016) argued for adopting the creative circles' approach in developing Saudi EFL middle school learners' reading comprehension. The study has found that the creative circles have improved the reading comprehension for the experimental group. The circle creative approach implies the adoption of collaborative reading as a teaching/learning technique, explicit teaching of reading skills, attention to low-level and high-level reading processes, and metacognitive awareness.

\section{The Limitations of the Study}

The study is limited to comparing and reviewing the aspects of similarities and differences between traditional and creative teaching approaches in the Saudi teaching and learning context. It also explores the shortcomings in the previous research done in the area of creativity and its relationship to the Saudi learning context. However, the study does not apply an experimental or empirical methodology for evaluating the current status of creativity in Saudi Arabia's teaching and learning environment.

\section{Conclusion}

The studies tackling the aspects of creativity in Saudi EFL teaching-focused specifically on the product represented in learning outcomes and did not pay enough attention to the cognitive process of creativity and its mechanism in EFL learners' minds. These studies do not address creativity as an individual talent that is different from person to person; Rather, they focused on creativity as an acquired thinking skill that can be developed through practicing certain tasks inside the classroom. In this way, they disregard the individual differences existing among learners in thinking and cognitive skills, which stripped creativity off its power as an avenue toward learning the English language in Saudi Arabia. Arabia The Saudi studies dealing with the associations between creative thinking and EFL learners are theoretical, and they are descriptive. These studies focused on the impediments which are visible in the cultural and religious context. In addition, these studies lack the empirical approach toward measuring creativity which can bring about accurate and valid results through which creativity can be measured for Saudi EFL learners. The studies done in the area of creativity in teaching EFL are few and the studies tackling the applications of creativity in the Saudi EFL environment are scarce. Creativity in teaching is mainly centered on how EFL teachers could adopt critical thinking pedagogy to the materials they delivered to their students. Creativity cultivates into the minds of EFL learners the skills of self-directed learning and turns them into autonomous learners who are capable of creating and producing knowledge rather than reproducing and retrieving it. Thus, mastering the skills of creative 
thinking can help improve the competency and proficiency of EFL learners in Saudi Arabia. Teachers' perception of learners' aptitude for knowledge acquisition largely shapes their teaching approach. In addition, adopting a specific teaching approach depends on

numerous variables like teachers' knowledge, education, cultural values, religious beliefs, teaching experience, empathy, intercultural communication, open-mindedness, and so on. The studies concerned with creativity in teaching and learning languages in Saudi EFL have focused on the finished product rather than describing the process of teaching itself or learning itself. That is to say, these studies focused on the learner himself rather than the ways through which the learning process can be creatively motivated. This has focused the shift of creativity on textbook design, learning objectives. However, the issue of fulfilling the conditions of a creative thinking environment for learners and improving the cognitive process in creative thinking has not been adequately studied.

\section{Recommendations}

The present study recommends that courses of modern philosophy and critical thinking should be delivered to the Saudi English teachers during their university studies. In addition, students should be familiarized with elementary courses in modern philosophy and critical thinking skills. The cultural and contextual barriers opposing creativity should be completely uprooted since their residue is still repressed in the minds of many people. Accordingly, students and learners should be exposed to programs that help them get rid of these cognitive and cultural barriers. In addition, empirical studies on creativity and its impact on EFL learners' minds in Saudi Arabia should be strongly conducted.

\section{References}

Abbasian, R., \& Khajavi, Y. (2010). Lexical attrition of general and special English words after years of non-exposure: The case of Iranian teachers. English Language Teaching, 3(3), 47-53. https://doi.org/10.5539/elt.v3n3p47

Ahmad, J. (2015). Traditional \& Socio-Cultural Barriers to EFL Learning: A Case Study. English Language Teaching, 8(12), 191-208. https://doi.org/10.5539/elt.v8n12p191

Al Dameg, K. A. (2011). The suitable age for learning foreign languages in public education. Damascus

Albawardi, A., \& Jones, R. H. (2019). Vernacular mobile literacies: Multimodality, creativity and cultural identity. Applied Linguistics Review, 11(4), 649-676. https://doi.org/ 10.1515/applirev-2019-0006

Albedaiwi, S. A. (2014). EFL materials in public school classrooms in Saudi Arabia: An investigation of the extent to which teachers engage in materials/textbooks development in order to design learning experiences to meet the needs of their students as an indicator of teacher autonomy (Ph.D. thesis). Glasgow: University of Glasgow

Aldujayn, N. N. (2019). Attitudes Toward Creativity Among Saudi EFL Teachers. The University of Toledo. ProQuest Dissertations Publishing, 2019. 28355518.

Aldujayn, N., \& Alsubhi, A. M. (2020). Saudi EFL Teachers' interpretation toward creativity. English Language Teaching, 13(6), 162-171. https://doi.org/10.5539/elt.v13n6p162

Alfallaj, S. (2017). Reading Competence of the Saudi EFL Learner: Empowering the Teachers through Linguistics. Advances in Language and Literary Studies, 8(3), 12-17. https://doi.org/10.7575/aiac.alls.v.8n.3p.12

Al-Ghamdi, M. A. (2018). Arabic learners' preferences for Instagram English lessons. English Language Teaching, 11(8), 103-112. https://doi.org/10.5539/elt.v11n8p103

Al-Ghamdi, M., \& Al-Bargi, A. (2017). Exploring the application of flipped classrooms on EFL Saudi students' speaking skills. International Journal of Linguistics, 9(4), 28-46. https://doi.org/10.5296/ijl.v9i4.11729

Alharthi, T. (2012). Vocabulary attrition of Saudi EFL graduating at Jeddah Teachers College (Unpublished doctoral dissertation. University of Essex, Colchester, UK).

Alharthi, T. (2014). The Impact of Attrition on Vocabulary Knowledge among Saudi Teachers. English Language Teaching, 7(4), 111-118. https://doi.org/10.5539/elt.v7n4p111

Al-Hazmi, S. (2017). Current Issues in English Language Education in the Kingdom of Saudi Arabia, Journal of Modern Language, 6(2), 130-150.

Al-Jarf, R. (2015). Discourse and creativity issues in EFL creative writing on Facebook. International Journal of Signs and Semiotic Systems, 4(1), 54-81. https://doi.org/10.4018/ijsss.2015010103

Alnefaie, S. K., \& Gritter, K. (2016). 'Teachers' role in the development of EFL curriculum in Saudi Arabia: the 
marginalized status'. Cogent Education, 3(1), 1-14. https://doi.org/10.1080/2331186X.2016.1240008

Alnofaie, H. (2013). A framework for implementing critical thinking as a language pedagogy in EFL preparatory programs. Thinking Skills and Creativity, 10, 154-158. https://doi.org/10.1016/j.tsc.2013.09.002

Al-Qahatani, A. A., \& Lin, M. (2016). The Impact of Creative Circles on EFL Learners' Reading Comprehension. Theory and Practice in Language Studies, 6(8), 1519-1530. https://doi.org/10.17507/tpls.0608.01

Al-Qahtani, A. A. (2016). Do Saudi EFL Teachers Promote Creativity in Their Classrooms? English Language Teaching, 9(4), 11-23. https://doi.org/10.5539/elt.v9n4p11

Alrashidi, O., \&Phan, H. (2015). Education Context and English Teaching and Learning in the Kingdom of Saudi Arabia: An Overview. English Language Teaching, 8(5), 33-44. https://doi.org/10.5539/elt.v8n5p33

Al-Rubaat, A. M., \& Alshammari, H. A. (2020). Analysis of Phonetic and Phonological Constraints of Saudi EFL Learners. English Language Teaching, 13(1), 63-72. https://doi.org/10.5539/elt.v13n1p63

Al-Seghayer, K. (2014). The Actuality, Inefficiency, and Needs of EFL Teacher-Preparation Programs in Saudi Arabia. International Journal of Applied Linguistics \& English Literature, 3(1), 143-151. https://doi.org/10.7575/aiac.ijalel.v.3n.1p.143

Al-Zahrani, N. (2017). Attitudes and Perceptions of Saudi EFL Teachers in Implementing Kingdom of Saudi Arabia's Vision 2030. International Journal of English Language Education, 5(1), 83-99. https://doi.org/10.5296/ijele.v5i1.10733

Assulaimani, T. (2019). The Future of Teaching English in Saudi Arabia. Universal Journal of Educational Research, 7(8), 1623-1634. https://doi.org/10.13189/ujer.2019.070801

Atkinson, K., \& Wells, C. (2000). Creative Therapies: A Psychodynamic Approach within Occupational Therapy. Nelson Thornes.

Baumeister, R. F., \& Leary, M. R. (1997). Writing Narrative Literature Reviews. Review of General Psychology, 1(3), 11-320. https://doi.org/10.1037/1089-2680.1.3.311

Bierling, R. M. (1990). Foreign language vocabulary attrition: A study of college-level Spanish students over an 18-month period (Unpublished Ph.D. thesis. Michigan State University, East Lansing, MI).

Boden, M. (1999). 'Computer models of creativity. In Sternberg, R. J. (Ed.), Handbook of Creativity. Cambridge: Cambridge University Press, 351-72. https://doi.org/10.1017/CBO9780511807916.020

Boden, M. A. (1994). What is creativity? In M. A. Boden (Ed.), Dimensions of creativity (pp. 75-118). Cambridge, MA: MIT Press. https://doi.org/10.7551/mitpress/2437.001.0001

Bruce, S. (2013). Secularization: In Defence of an Unfashionable Theory. Oxford: Oxford University Press.

Cariani, P. (1997). The emergence of new signal-primitives in neural systems. Intellectica, 2(25), 95-143. https://doi.org/10.3406/intel.1997.1560

Carter, R. (2005). Language, and Creativity: The Art of Common Talk. Routledge, London.

Coleman, E. J. (1998). Creativity and Spirituality: Bonds between Art and Religion. State University of New York, Albany.

Cropley, A. (2006). Dimensions of Creativity: A Social Approach. Roeper Review, Spring, 28(3), 125-130. https://doi.org/10.1080/02783190609554351

Damian, R. I., \& Simonton, D. K. (2015). Four Psychological Perspectives on Creativity. Emerging Trends in the Social and Behavioral Sciences: An Interdisciplinary, Searchable, and Linkable Resource. https://doi.org/10.1002/9781118900772.etrds0134

De Bot, K., Lowie, W., \& Verspoor, M. (2007). 'A dynamic systems theory approach to second language acquisition. Bilingualism: Language and Cognition, 10(1), 7-21. https://doi.org/10.1017/S1366728906002732

Elkjær, B., \& Simpson, B. (2006). “Towards a Pragmatic Theory of Creative Practice," paper presented at the Second Organization Studies Summer Workshop Return to Practice: Understanding Organization as It Happens, Mykonos, Greece, June 15-16. Retrieved from http://pure.au.dk/portal/files/58/ Elkjaer_Simpson_OS_2006.pdf

Elyas, T., \& Michelle, P. (2010). Saudi Arabian educational history: Impacts on English language teaching. Education, Business and Society. Contemporary Middle Eastern Issues, 3(1), 136-145. https://doi.org/10.1108/17537981011047961 
Fatani, S. A. (2016). Reflections: 10 Challenges to Address in order to Improve the Teaching of English Language in Education to Fulfill the 2030 Vision. Retrieved from http://samirportfolio1.blogspot.com/2016/05/10-2030.html

Finke, R. A., Ward, T. B., \& Smith, S. M. (1992). Creative Cognition: Theory, Research, and Application. Cambridge, MA: MIT Press.

Gurudeo, A. T., \& Patrick., M. (2018). Traditional vs Non-traditional Teaching and Learning Strategies - the case of E-learning! International Journal For Mathematics Teaching And Learning, 19(1), 129-158.

Harasim, L., Hiltz, S. R., Teles, L., \& Turoff, M. (1995) Learning Networks: A Field Guide to Teaching and Learning Online, Cambridge MA: MIT Press. Harzallah, H. (2018). Palestinian teachers' views on the factors that limit students' creativity and some possible strategies to overcome them. Research in Social Sciences and Technology, 3(2), 40-57. https://doi.org/10.46303/ressat.03.02.3

Harding, S. (1987). Convicted by the Holy Spirit: The rhetoric of fundamental Baptist conversion. American Ethnologist, 14(1), 167-181. https://doi.org/10.1525/ae.1987.14.1.02a00100

Harper, G. (2014). The Future for Creative Writing. Oxford: Wiley-Blackwell. https://doi.org/10.1002/9781118476826

Hofweber, J., \& Graham, S. (2017). Linguistic creativity in language learning: Investigating the impact of creative text materials and teaching approaches in the second language classroom. Scottish Languages Review, 4(33), 19-28. Retrieved from https://scilt.org.uk/Portals/24/Library/slr/issues/33/33-02\%20Hofweber-Graham.pdf

Holy Qur'an. (A.Y. Ali, Trans. \& T. Griffith, Ed.). (2001). Wordsworth.

Hoover, J. (2004). Perpetual Creativity in the Perfection of God: Ibn Tayimiyya's Hadith Commentary on God's Creation of this World. Journal of Islamic Studies, 15(3), 287-329. https://doi.org/10.1093/jis/15.3.287

Hrešć, T. (2016). Ways of promoting creativity in EFL classroom (Master's thesis). Retrieved from http://darhiv.ffzg.unizg.hr/id/eprint/6532/1/Hresc\%2C\%20Tihana.pdf

Iqbal, C. (2017). Assessing Creativity and Innovation in Islam. The International Journal of Religion and Spirituality in Society, 7(3), 55-67. https://doi.org/10.18848/2154-8633/CGP/v07i03/55-67

Isýkoyn, N., 1vrendi., A., \& Sahin, A. (2007). An in-depth look to the process of student teaching through the eyes of candidate teachers. Eurasian Journal of Educational Research, 26(2), 131-142.

Johnson, I. (2017). Creative teaching: using creative teaching methods in a student-centered EFL Environment. (Master's project). Accessed from https://repository.usfca.edu/capstone/675

Kim, J. (2006). Emergence: Core ideas and issues. Synthese, 151(3), 547-59. https://doi.org/10.1007/s11229-006-9025-0

Kuppinger, P. (2017). Piously creative: Islam, art, and creativity in Stuttgart, Germany. Culture, and Religion, 18(4), 428-447. https://doi.org/10.1080/14755610.2017.1376692

Larsen-Freeman, D., \& Cameron, L. (2008) Complex Systems and Applied Linguistics, Oxford: Oxford University Press.Moskovsky, C. (2018). EFL teaching and learning in Saudi Arabia. In C. Moskovsky \& M. Picard (Eds.), English as a foreign language in Saudi Arabia: New insights into teaching and learning English (pp. 4-69). https://doi.org/10.4324/9781315688466-2

Liton, H. A. (2013). EFL teachers' perceptions, evaluations and expectations about English language courses as EFL in Saudi universities. International Journal of Instruction, 6(2), 19-33.

Lubart, T. I. (1999). 'Creativity across cultures'. In Sternberg, R. J. (Ed.), Handbook of Creativity. Cambridge: Cambridge University Press: 339-50. https://doi.org/10.1017/CBO9780511807916.019

Marefat, H., \& Rouhshad, A. (2007). Second language attrition: Are different nouns equally likely to be lost. Porta Linguarum, 8(2), 85-98. https://doi.org/10.30827/Digibug.31621

Mustafa, Z. (2015). The tyranny of language in education: The problem and its solution. Karachi: Oxford University Press.

Pechenizka, S., \& Zavalna, O. (2020). Disadvantages of traditional teaching foreign languages to modern students of Generation Z. EUROPEAN HUMANITIES STUDIES: State and Society, 1, 102-110. https://doi.org/10.38014/ehs-ss.2020.1.08

Pietsch, M., \& Williams, J. (2005). I felt like a teacher today": Beginning teachers and professional identity. In 
Conference Proceedings of the 33rd Annual Australian Teacher Education Association, 6-9 July, Melbourne.

Plucker, J. A., \& Renzulli, J. S. (1999). Psychometric approaches to the study of human creativity. In R. J. Sternberg (Ed.), Handbook of creativity (. 35-61). Cambridge University Press. https://doi.org/10.1017/CBO9780511807916.005

Preminger, A., \& Brogan, T. V. F. (1993). The Princeton Encyclopaedia of Poetry and Poetics. Princeton, NJ: Princeton University Press.

Rajab, H. (2013). Developing speaking and writing skills of L1 Arabic EFL learners through the teaching of IPA phonetic codes. Theory and Practice in Language Studies, 3(4), 653-659. https://doi.org/10.4304/tpls.3.4.653-659

Rauf, M. (2015). Best practices in English language testing at the university preparatory year programs. In A. K. Hamdan (Ed.), Teaching and learning in Saudi Arabia: Perspectives from higher education (85-205). Rotterdam: Sense Publisher. https://doi.org/10.1007/978-94-6300-205-9_10

Reeves, C. K., \& Kazelskis, R., (1985). Concerns of preservice and in-service teachers. Journal of Educational Research, 78(5) 267-271. https://doi.org/10.1080/00220671.1985.10885614

Rhodes, M. (1987). 'An analysis of creativity. In S. G. Isaksen (ed.) Frontiers of Creativity Research: Beyond the Basics, Buffalo, NY: Bearly, pp. 216-22.

Richards, J. C. (2013). Creativity in language teaching. Iranian Journal of Language Teaching Research, 1(3), 19-43. Retrieved from https://files.eric.ed.gov/fulltext/EJ1127396.pdf

Roth, W., \& Duit, R. (2003) Emergence, flexibility, and stabilization of language in a physics classroom. Journal of Research in Science Teaching, 40(9), 869-97. https://doi.org/10.1002/tea.10114

Sadykova, G., \& Shelestova, V. (2016). Creativity development: The role of foreign language learning. International Journal of Environmental \& Science Education, 11(15), 8163-818. Retrieved from https://files.eric.ed.gov/fulltext/EJ1118314.pdf

Salter, G. (2003). Comparing online and traditional teaching - a different approach. Campus-Wide Information Systems, 20(4), 137-145. https://doi.org/10.1108/10650740310491306

Samuelson, D. B., Divaris, K., \& De Kok, I. J. (2017). Benefits of Case-Based versus Traditional Lecture-Based Instruction in a Preclinical Removable Prosthodontics Course. $J$ Dent Educ, 81(4), 387-394. https://doi.org/10.21815/JDE.016.005

Schoff, S. (2016). The value of creativity in English language education. The CATESOL Journal, 28(2), 31-35. Retrieved from http://www.catesoljournal.org/wp-content/uploads/2016/10/CJ28.2_schoff1.pdf

Shamim, F., \& Rashid, U. (2019). The English/Urdu-medium divide in Pakistan: Consequences for learner identity and future life chances. Journal of Education and Educational Development, 6(1), 43-61. https://doi.org/10.22555/joeed.v6i1.2235

Slavin, R. E. (1995). Cooperative learning: Theory, research, and practice (2nd ed.). Boston: Allyn and Bacon.

Slobin, D. I. (2005). From ontogenesis to phylogenesis: What can child language tell us about language evolution? In S. T. Parker, J. Langer, and C. Milbrath (eds.), Biology and Knowledge Revisited: From Neurogenesis to Psychogenesis. London: Lawrence Erlbaum, pp. 255-86.

Snyder, H. (2019). Literature review as a research approach ology: An overview and guidelines. Journal of Business Research, 104, 333-339. https://doi.org/10.1016/j.jbusres.2019.07.039

Sokol, A., Oget, D., Sonntag, M., \& Khomenko, N. (2008). The development of inventive thinking skills in the upper secondary language classroom. Thinking Skills and Creativity, 3(1), 34-46. https://doi.org/10.1016/j.tsc.2008.03.001

Steels, L. (2005) The emergence and evolution of linguistic structure: From lexical to grammatical communication systems. Connection Science, 17(3-4), 213-30. https://doi.org/10.1080/09540090500269088

Stephen, M. (1997). Cargo cults, cultural creativity, and autonomous imagination. Ethos, 25(3), 333-358. https://doi.org/10.1525/eth.1997.25.3.333

Syed, Z. (2003). The Socio-cultural Context of English Language Teaching to the Gulf. TESOL Quarterly, 37(2), 337-341. https://doi.org/10.2307/3588508 
Tin, T. B. (2015). Creativity in second-language learning. In R. H. Jones (Ed.), The Routledge handbook of language and creativity (pp. 433-449). London: Routledge

Tomasello, M. (2000). The item-based nature of children's early syntactic development. Trends in Cognitive Sciences, 4(4), 156-63. https://doi.org/10.1016/S1364-6613(00)01462-5

Torraco, R. J. (2005). Writing integrative literature reviews: Guidelines and examples. Human Resource Development Review, 4(1), 356-367. https://doi.org/10.1177/ 1534484305278283

Tosey, P. (2006). Interfering with the interference. In N. Jackson, M. Oliver, M. Shaw, \& J. Wisdom (Eds.), Developing Creativity in Higher Education, London: Routledge, pp. 29-42.

Tularam, G. A., \& Machisella, P. (2018). Traditional vs non-traditional teaching and learning strategies: The case of e-learning! International Journal for Mathematics Teaching and Learning, 19(1), 129-158. Retrieved from http://www.cimt.org.uk/ijmtl/index.php /IJMTL/article/view/21

Waldron, N. L., \& McLeskey. (2010). Establishing a collaborative school culture through comprehensive school reform. Journal of Educational \& Psychological Consultation, 20(1), 58-74. https://doi.org/10.1080/10474410903535364

Wang, T. (2007). The Comparison of the Difficulties between Cooperative Learning and Traditional Teaching Approach s in College English Teachers. The Journal of Human Resource and Adult Learning, 3(2), 23-30.

Yerxa, D. A. (2016). Religion and Innovation. Antagonists or Partners? London \& New York: Bloomsbury Publishing.

Zaid, M. A. (2011). Language Acquisition, Linguistic Creativity and Achievement: Insights from the Qur'an. Kemanusiaan, 18(2), 75-100

\section{Copyrights}

Copyright for this article is retained by the author(s), with first publication rights granted to the journal.

This is an open-access article distributed under the terms and conditions of the Creative Commons Attribution license (http://creativecommons.org/licenses/by/4.0/). 